\title{
Potential effects of climate change on the distribution of an endangered species: Melanophryniscus montevidensis (Anura: Bufonidae)
}

\author{
Carolina Toranza ${ }^{1,2}$ and Raúl Maneyro \\ ${ }^{1}$ Grupo Biodiversidad y Ecología de la Conservación (BEC), Facultad de Ciencias, Universidad de la República. Iguá 4225 \\ Piso 8 Sur, Montevideo, Uruguay. E-mail: ctoranza@gmail.com. \\ ${ }^{2}$ Centro Interdisciplinario de Respuesta al Cambio y la Variabilidad Climática (CIRCVC), Espacio Interdisciplinario, \\ Universidad de la República. Rodó 1843, Montevideo, Uruguay. \\ ${ }^{3}$ Laboratorio de Sistemática e Historia Natural de Vertebrados, Facultad de Ciencias, Universidad de la República. Iguá 4225 \\ Piso 9 Sur, Montevideo, Uruguay. E-mail: rmaneyro@gmail.com.
}

\begin{abstract}
Potential effects of climate change on the distribution of an endangered species: Melanophryniscus montevidensis (Anura: Bufonidae). Species distributions are linked with climate. Among the effects predicted by the Intergovernmental Panel on Climate Change are changes in precipitation patterns and increases in mean temperatures-factors potentially having a major impact on threatened, rare, and endemic species. Using models to forecast possible changes in the distributions of different species under different climatechange scenarios, we can identify probable impacts on species and build effective conservation strategies. We modeled the effects of two climate-change scenarios on the geographical distribution of the regionally endemic bufonid, Melanophryniscus montevidensis, categorized as vulnerable by the IUCN and as endangered by the Uruguayan Red List of amphibians. Ecological niche models were generated to describe the present and possible future distributions of this species in 2050 and 2080, given severe (A2) and moderate (B2) climatic changes. Legacy data for M. montevidensis were obtained from Uruguayan biocollections and climate data were acquired from the WorldClim database. At present, M. montevidensis could occur along the Atlantic Uruguayan coast and a small section of the southern Brazilian coast. However, changes in climate may lead to a loss of suitable environmental conditions for this toad; thus, this endangered species is vulnerable and in urgent need of protection.
\end{abstract}

Keywords: amphibians, geographical distribution, niche models, threatened species, Uruguay.

Received 5 April 2013.

Accepted 25 October 2013.

Distributed December 2013. 


\begin{abstract}
Resumen
Efectos potenciales del cambio climático sobre la distribución de una especie amenazada: Melanophryniscus montevidensis (Anura: Bufonidae). La distribución de las especies está relacionada con el clima. Entre los efectos predichos por el Panel Intergubernamental de Cambio Climático, se encuentran los cambios en los patrones de precipitación y los aumentos en la temperatura media global. Estos factores tienen un impacto mayor en especies amenazadas, raras o endémicas. Usando modelos para predecir posibles cambios en la distribución de especies bajo diferentes escenarios de cambios climático, podemos identificar probables impactos sobre las especies y construir estrategias efectivas de conservación. Modelamos los efectos de dos escenarios de cambio climático en la distribución geográfica de un bufónido regionalmente endémico, Melanophryniscus montevidensis, categorizado como Vulnerable por la UICN, y como amenazado según la Lista Roja de Anfibios de Uruguay. Fueron generados modelos de nicho para describir la distribución presente y futura en 2050 y 2080, bajo los escenarios A2 (severo) y B2 (moderado). Los registros fueron obtenidos de las principales colecciones del país y los datos climáticos se tomaron de la base de datos WorldClim. Actualmente, M. montevidensis podría encontrarse en la costa Atlántica de Uruguay, y una pequeña parte de la costa del sureste de Brasil. Sin embargo, los cambios en el clima pueden llevar a la pérdida de condiciones ambientales adecuadas para este anfibio, por lo que la especie amenazada es vulnerable y necesita protección urgente.
\end{abstract}

Palabras Clave: anfibios, distribución geográfica, especies amenazadas, modelos de nicho, Uruguay.

\begin{abstract}
Resumo
Efeitos potenciais da mudança climática sobre a distribuição de uma espécie ameaçada: Melanophryniscus montevidensis (Anura: Bufonidae). A distribuição das espécies está relacionada ao clima. Entre os efeitos previstos pelo Painel Intergovernamental sobre Mudanças Climáticas encontram-se mudanças nos padrões de precipitação e aumento na temperatura média global. Esses fatores têm um impacto maior sobre espécies ameaçadas, raras ou endêmicas. Usando modelos para prever possíveis alterações na distribuição das espécies sob diferentes cenários de mudanças climáticas, podemos identificar prováveis impactos sobre as espécies e construir estratégias de conservação eficazes. Nós modelamos os efeitos de dois cenários de mudanças climáticas na distribuição geográfica do bufonídeo regionalmente endêmico Melanophryniscus montevidensis, categorizado como Vulnerável pela IUCN e como ameaçado de acordo com a Lista Vermelha de Anfíbios do Uruguai. Foram gerados modelos de nicho para descrever a distribuição presente e futura em 2050 e 2080 nos cenários A2 (grave) e B2 (moderado). Os registros foram obtidos a partir das principais coleç̃̃es do país, e os dados climáticos, do banco de dados WorldClim. Atualmente, M. montevidensis poderia ser encontrado no litoral atlântico do Uruguai e uma pequena parte da costa do sudeste do Brasil. No entanto, mudanças no clima podem provocar a perda das condições ambientais adequadas para esse anfíbio, indicando que a espécie ameaçada é vulnerável e precisa de proteção urgente.
\end{abstract}

Palavras-chave: anfíbios, distribuição geográfica, espécies ameaçadas, modelos de nicho, Uruguai. 


\section{Introduction}

Owing to the global declines in populations of amphibians, anurans are one of the most endangered groups of vertebrates, with $32 \%$ of the species included in IUCN threatened categories (Stuart et al. 2004). The present extinction rate of this group is thought to be greater than its basal extinction rate $(\mathrm{McCallum}$ 2007). The process of anuran population declines involves multiple factors, including habitat loss, pollution, UV radiation, biological invasions, diseases, and climate change (Alford and Richards 1999).

There is a general consensus that climate change is occurring. The increase in greenhouse gases has led to an increase in the mean global temperature during the last century, and this, in turn, drives many other, correlated climatic changes (IPCC 2001), such as sea-level rise, changes in precipitation patterns, and an increase in global average temperatures (1.8$4.0^{\circ} \mathrm{C}$ ) that are expected in the 21 st century. Such changes are expected to cause further population declines in anurans (Pound et al. 1999), as a result of diminished fitness and survival (Reading 2007), phenological modifications (Gibbs and Breisch 2001), and geographical shifts in species distributions (Hickling et al. 2006) that lead to species extinction (Pounds et al. 1999). Moreover, studies propose that climate change is promoting the expansion of the Batrachochytrium dentrobatidis, the fungus responsible for chytridiomycosis (Rohr and Raffel 2010).

The Montevideo red-belly toad, Melanophryniscus montevidensis (Philippi 1902), is a regionally endemic species, distributed along the southern coast of Uruguay, with a few records of species occurrence on the Brazilian coast (Núñez et al. 2004, Bernardo-Silva et al. 2012). Melanophryniscus montevidensis has been recognized globally as "Vulnerable" by the IUCN (IUCN 2013) and as "Endangered" in the Uruguayan Red List of amphibians (Canavero et al. 2010). The biology of this species is poorly understood, but preliminary studies show that this toad is an "explosive breeder" that breeds in ephemeral ponds with sandy soils (Maneyro and Carreira 2012). Given the documented decline in populations, narrow geographical distribution, and fragmentation of the toad's habitat, $M$. montevidensis is threatened. The species usually in found along the edges of the Río de la Plata and the Atlantic Ocean, where it interfaces with urban development activities related to tourism and housing construction (Maneyro and Carreira 2006). Some researchers (Langone 1994, Maneyro and Carreira 2012) think that $M$. montevidensis may be locally extinct in the departments of Montevideo and Canelones, and critically endangered in most of the Departamento de Maldonado. Additionally, Borteiro et al. (2009) reported that some anurans sympatric with $M$. montevidensis are infected with chytridiomycosis.

During the past century, the documented changes in the Uruguayan climate include: an increment of approximately $20 \%$ in mean cumulative annual precipitation (Kane 2002); a rise in mean annual temperature of Montevideo from 1883-2003 (Bidegain et al. 2005); a warming trend with respect to mean and extreme temperatures in the summer and winter, with the latter more pronounced (Rusticucci and Renom 2008, Renom 2009); and an increase in the number of extreme precipitation events in the last 40 years (Marengo et al. 2010). Furthermore, an intensification of these changes over the 21st century is expected (DINAMA 2005).

We analyzed potential negative effects of climate change on Melanophryniscus montevidensis by modeling with envelope niche models the spatial distribution of the species, and forecasting the potential changes in its distribution in the event of two climate-change scenarios (A2, severe; B2, moderate) of the Intergovernmental Panel on Climate Change (IPCC) in 2050 and 2080, respectively. 


\section{Materials and Methods}

\section{Study Area}

Uruguay has a continental surface area of $176,215 \mathrm{~km}^{2}$ in the southeastern part of South America $\left(30-35^{\circ} \mathrm{S}\right.$ and $\left.53.5-58.5^{\circ} \mathrm{W}\right)$. The landscape is dominated by plains and peneplains and is composed of areas of hills and ravines reaching a maximum elevation of $513 \mathrm{~m}$. The country has $650 \mathrm{~km}$ of shoreline, extending from the fluvial coast of the Río de la Plata in the southwest to the Atlantic coast in the southeast. Uruguay has a temperate, wet climate with hot summers (type "cfa" sensu Kottek et al. 2006) and a mean annual temperature of $17.5^{\circ} \mathrm{C}$. Mean annual precipitation varies between $1100 \mathrm{~mm}$ and $1400 \mathrm{~mm}$ along a south-north gradient (DINAMA, 2005).

\section{Biological and Climatic Databases}

Species occurrence data were obtained from the Colección de Zoología Vertebrados, Facultad de Ciencias (ZVCB) and the Museo Nacional de Historia Natural (MNHN) in Uruguay. We compiled 114 records of Melanophryniscus montevidensis from 47 localities (Figure 1), some of which had been georeferenced (Nuñez et al. 2004). We used the digital cells of the Military Geographic Institute of Uruguay and
Google Earth version 7.1.1 (Google, Inc.) to determine geographical coordinates for the remaining records following the georeferencing techniques of Chapman and Wieczorek (2006).

Climatic data were acquired from the WorldClim database (WorldClim 2012). We used 36 climatic variables and one topographic variable, with a resolution of 2.5' arc-minutes $(\approx 5 \mathrm{~km})$ (Table 1). Experts of the WorldClim used ANUSPLIN-SPLINA software to interpolate layers of weather station records for the period of 1950-2000 (Hijmans 2005). Forecast climate layers correspond to projections of the HadCM3 model from the Hadley Center of the United Kingdom for the decades of 2050 and 2080, under the IPCC scenarios A2 (severe) and B2 (moderate), according to the $3^{\text {rd }}$ communication of the IPCC (IPCC 2001).

\section{Species Distribution Modeling}

The climate envelope model, which estimates the potential distribution of a species by correlating occurrence data with environmental predictors, is widely used to estimate the potential distribution of species (Lobo et al. 2010). The approach is rooted in ecological niche theory because it models a fragment of the fundamental niche of the species, which is defined as the "climatic niche" (Pearson and Dawson 2003). To model current and future

Table 1. List of environmental variables included in the Maxent models of current and future potential distribution of Melanophryniscus montevidensis. Data source: WorldClim. Subscripted numbers correspond to the month (i.e. $\mathrm{T}_{\min 1}=$ minimum temperature in January).

\begin{tabular}{|c|c|}
\hline Variables & Acronyms \\
\hline Monthly minimum temperature & 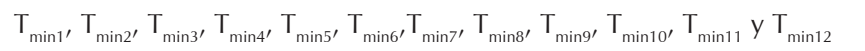 \\
\hline Monthly maximum temperature & $\mathrm{T}_{\max \times 1^{\prime}} \mathrm{T}_{\max 2^{\prime}} \mathrm{T}_{\max 3^{\prime}} \mathrm{T}_{\max 4^{\prime}} \mathrm{T}_{\max 5^{\prime}} \mathrm{T}_{\max 66^{\prime}}, \mathrm{T}_{\max 7}, \mathrm{~T}_{\max 8^{\prime}} \mathrm{T}_{\max 9}, \mathrm{~T}_{\max 10^{\prime}} \mathrm{T}_{\max 11} \mathrm{y} \mathrm{T}_{\max 12}$ \\
\hline Annual accumulated precipitation & 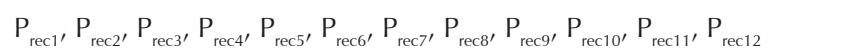 \\
\hline Mean elevation & Elev $_{\text {mean }}$ \\
\hline
\end{tabular}




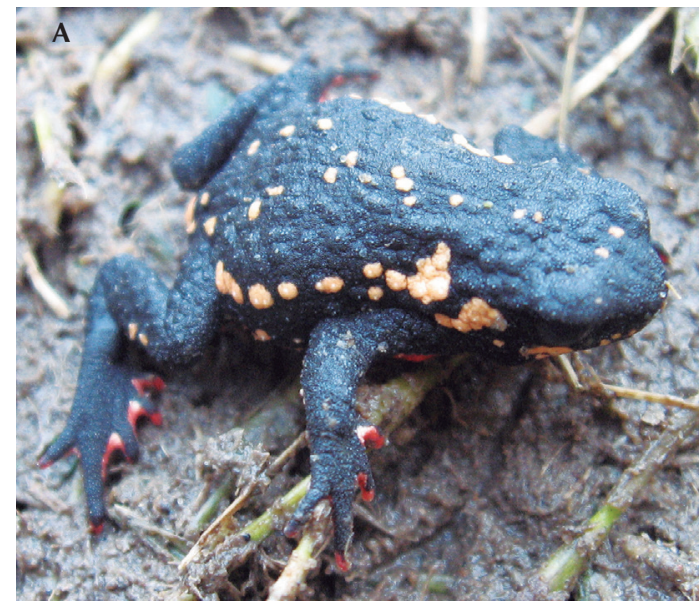

Figure 1. A) Melanophryniscus montevidensis, photo by Raúl Maneyro; (B) Map of the geographical distribution of species collections used in this study (ZVCB and MNHN).

geographical distributions of Melanophryniscus montevidensis, we applied Maximum Entropy Models, using Maxent Version 3.3.1, a type of climatic envelope model (Phillips et al. 2006). This program uses a machine-learning algorithm to estimate the probability of species occurrence at certain localities, based on the environmental conditions at sites where the species were recorded. Maxent has many practical advantages that make it easily applicable to occurrence data. It requires presence-only data, and functions with both continuous and categorical predictors. The program provides a continuous model output that can be categorized according to different thresholds, and provides results that can be interpreted with Geographic Information Systems (Phillips et al. 2006). Maxent is thought to be one of the most robust modeling approaches (Elith et al. 2006).

We ran Maxent using the default featuresi.e., 500 iterations, duplicate records elimination, the convergence threshold $=0.00001$ and the regularization parameter $\beta=1$ (Phillips et al.

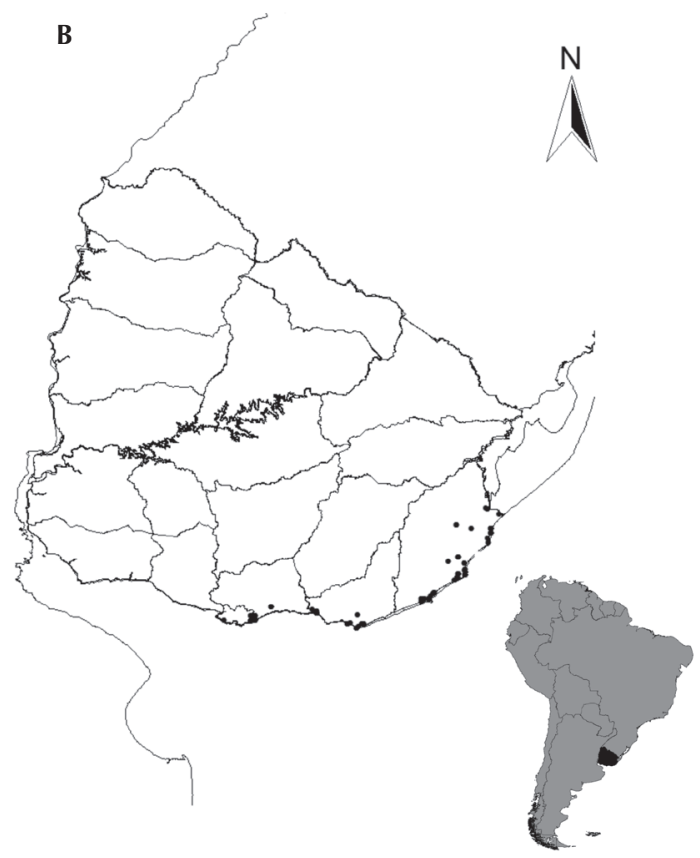

2006). To analyze the relationships among variables, we selected linear and quadratic relationships, as well as interactions between pairs of variables. The Jackknife option was used to evaluate the contribution of variables to the model. The sample was divided into training (70\%) and testing samples (30\%) used for model validation. Models accuracy were evaluated through the area under the curve (AUC), obtained from the receiver operating characteristic curve (ROC). We applied the "Minimum training presence" threshold to convert continuous maps into presence-absence distribution, as suggested for endemic and narrowly distributed species (Gomes-Cortes 2009).

\section{Results}

\section{Current Potential Distribution}

The modeling exercise indicated that Melanophryniscus montevidensis currently is distributed on the central and eastern coasts of 

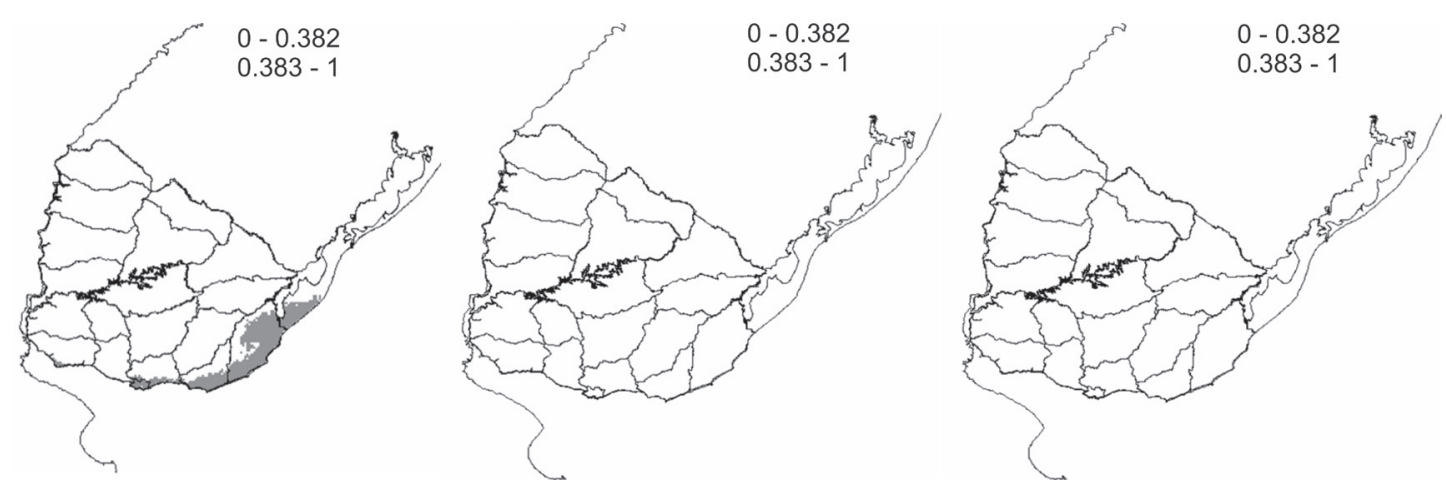

Figure 2. Potential distribution of Melanophryniscus montevidensis generated with Maxent, applying the "Minimum training presence" threshold. (A) Current potential distribution; (B) potential distribution at 2050 (under the A2 scenario); (C) potential distribution at 2050 (under the B2 scenario).

the Río de la Plata and Atlantic Ocean of Uruguay (departments of Montevideo, Canelones, Maldonado, and Rocha), and scarcely entering the Brazilian coast. As indicated by the model, the geographical extent of the species is approximately $9270 \mathrm{~km}^{2}$ (Figure 2A). These results agree with previous studies that also used niche models to estimate distribution of $M$. montevidensis (Bernardo-Silva et al. 2012), as well with the distribution proposed by the Global Amphibian Assessment, based on expert opinion (IUCN, 2013).

The training and test data yielded an AUC value of 0.998 , indicating the strength of the model. The threshold (minimum training presence) corresponded to 0.458 , whereas the training and test omission rates, as well as the $p$-value calculated by the binomial probability, were greater than 0.001 . The analysis of the relative contribution of the environmental variables to the Maxent model indicated that elevation and maximum temperatures of May, September, and January were the most important. The contribution of each variable to the model was $20.5 \%, 16.4 \%, 12.5 \%$, and $12.4 \%$, respectively. These variables increase in this proportion the regularized gain of the model when included.

\section{Future Potential Distribution}

Under both IPCC scenarios (A2 and B2), models predict a complete change of the prevailing climatic conditions to which the species would be subject in 2050 (Figures 2B, C). Should Melanophryniscus montevidensis not adapt to these climatic changes, the species will be extinct by the middle of the $21^{\text {st }}$ century. Models of the potential distribution of $M$. montevidensis in 2080 indicate that the climatic conditions would remain altered. However, under the B2 scenario of 2080, the model indicates suitable conditions for the species on the coast of the Department of Rocha.

\section{Discussion}

Ectothermic species are particularly sensitive to environmental change (Navas and Otani 2007). The current, modeled distribution of Melanophryniscus montevidensis based on climate conditions, coincides with previous distributions proposed for this species (BernardoSilva et al. 2012, IUCN 2013).

Climate change, and particularly temperature increase, is driving species poleward (Parmesan 2006). We found that predicted changes in 
temperature and precipitation for the southeastern portion of South America will promote a poleward shift in the distribution of Melanophryniscus montevidensis, potentially leading to their extinction in the midterm. According to the model, $M$. montevidensis responds to changes in maximum temperatures; thus, if high temperatures exceed tolerance levels (i.e., the maximum lethal temperature) $M$. montevidensis will be affected (Snyder and Weathers 1975). Like all anurans. these toads depend on cutaneous gas exchange for respiration (Duellman and Trueb 1994, Hermida et al. 2003), which is affected by changes in ambient temperature. We detected an influence of temperature on $M$. montevidensis distribution. However, this variable could be a surrogate of other variables (moisture, evapotranspiration) not included in the model.

The reproductive behavior of Melanophryniscus montevidensis may be impacted by climate change because explosive reproduction is linked to precipitation events that generate temporary ponds (Maneyro and Kwet 2008). Reproductive periods are constrained by high temperatures; thus, reproductive activity is uncommon in summer months. Not only must ponds form, they must persist long enough for the larvae to complete development. Extreme weather events such as heat waves and droughts affect South America and vary regionally. A recent study found an increase in climate variability (incidence of extreme events) between 1960 and 2000 in southeastern South America (Marengo et al. 2010). Of particular concern is the increasing trend in the maximum number of consecutive dry days (Marengo et al. 2010). Such increases in temperature and drought incidence could result in the desiccation of ponds and diminishing of the survival of premetamorphic stages, which require approximately a month to complete development (Garrido-Yrigaray 1989).

It has been proposed that climate change favors the expansion of Batrachochytrium dendrobatidis, the fungus responsible for chytridiomycosis (Lips et al. 2008). A synergistic interaction between climate change and the pathogenic chytrid fungus may be responsible for the extinction of other bufonid frog, the Monteverde harlequin frog (Incillus periglenes) (Pound et al. 2006). Although the relationship between climate change and chytridiomycosis was not evaluated here, this disease has been detected in wild populations of other amphibian species that coexist in the same ponds with Melanophryniscus montevidensis tadpoles in the Rocha Lagoon on the east coast of Uruguay (Borteiro et al. 2009).

Finally, shifts in species distribution induced by climate are especially dangerous for narrowly distributed species (Foden et al. 2008). For example, tropical montane species may be at serious risk, because altitudinal changes can decrease the extent of their ranges and ultimately force them to extinction (Colwell et al. 2008, Forero-Medina et al. 2010). Similarly, a study of the bufonid genus Atelopus, showed that the risk of extinction increases from the lowlands to mountain tops, because geographic ranges tend to decrease in size with increasing elevation (Pounds et al. 2006). According to our model, the distribution of Melanophryniscus montevidensis is primarily affected by elevation, as they are generally restricted to low elevations. However, we think that the geographic restriction of $M$. montevidensis to coastal environments may be analogous to species adapted to living near mountain tops. The potential southward migration of climate conditions could narrow its range, because the Río de la Plata and the Atlantic Ocean constitute barriers for its dispersion to more southern latitudes.

Our results suggest that there is a pressing need for further study on the biology of Melanophryniscus montevidensis, especially its physiology and autoecology. Such information would be key for determining its response to predicted climate changes and its ability to adapt to such change. Given the multiple threats currently faced by the species and our findings presented here, we suggest reconsideration of its 
global conservation status, including an increase in threat category to attend to the features stated by several authors (Canavero et al. 2010, Laufer 2012, Maneyro and Carreira 2012). We also recommend the implementation of active in-situ and ex-situ conservation actions, including an increase in the number of protected areas within its geographical range (Bernardo-Silva et al. 2012) and the application of ex-situ conservation measures based on previous successful experiences with other species within Bufonidae (AmphibianArk 2013).

\section{Acknowledgments}

This article was funded by a National Graduate Fellowship from ANII (Agencia Nacional de Investigación e Innovación) and performed within the Master's Program for Biology of PEDECIBA (Programa de Desarrollo de las Ciencias Básicas), Facultad de Ciencias, Universidad de la República, Uruguay. We thank Dr. Christine Lucas for revision of English.

\section{References}

Alford, R. A. and S. J. Richards. 1999. Global amphibian declines: a problem in applied ecology. Annual Review of Ecology and Systematics 30: 133-165.

AmphibianArk. 2013. Amphibian ark: keeping threatened amphibian species afloat: an Online Reference (January 2013). Web site of Amphibian Ark Organization accessible at http://www.amphibianark.org. Captured on 20 February 2013.

Bernardo-Silva, J., C. Martins-Ferreira, R. Maneyro, and T. R. Ochotorena de Freitas. 2012. Identification of priority areas for conservation of two endangered parapatric species of Red-bellied toads using ecological niche models and hotspot analysis. Natureza \& Conservação 10: 207-213.

Bidegain, M., R. M. Caffera, F. Blixen, V. Pshennikov, J. J. Lagomarsino, E. A. Forbes, and G. J. Nagy. 2005 Tendencias Climáticas, Hidrológicas y Oceanográficas en el Río de la Plata y Costa Uruguaya. Pp. 137-143 in V. Barros, A. Menéndez and G. J. Nagy (eds.), El Cambio Climático en el Río de la Plata. Buenos Aires. CIMA.
Borteiro, C., J. C. Cruz, F. Kolenc, and A. Aramburu. 2009. Chytridiomycosis in frogs from Uruguay. Diseases of Aquatic Organisms 84: 159-162.

Canavero, A., S. Carreira, J. A. Langone, F. Achaval, C. Borteiro, A. Camargo, I. da Rosa, A. Estrades, A. Fallabrino, F. Kolenc, M. M. López-Mendilaharsu, R. Maneyro, M. Meneghel, D. Núñez, C. M. Prigion, and L. Ziegler. 2010. Conservation status assessment of the amphibians and reptiles of Uruguay. Iheringia, Série Zoologia 100: 5-12.

Chapman, A. D. and J. Wieczorek. 2006. Guide to Best Practices for Georeferencing. Copenhagen. Global Biodiversity Information Facility. 90 pp.

Colwell, R. K., G. Brehm, C. L. Cardelús, A. C. Gilman, and J.T. Longino. 2008. Global warming, elevational range shifts, and lowland biotic attrition in the wet tropics. Science 322: 258-261.

Duellman W. E. and L. Trueb. 1994. Biology of Amphibians. Baltimore. The Johns Hopkins University Press. 613 pp.

DINAMA. 2005. Análisis de la estadística climática y desarrollo y evaluación de escenarios climáticos $e$ hidrológicos de las principales cuencas hidrográficas el Uruguay y de su Zona Costera (Río Uruguay, Río Negro, Laguna Merín, Río de la Plata y Océano Atlántico). Informe Técnico. Montevideo Unidad de Cambio Climático. 84 pp.

Elith, J., C. H. Graham, R. P. Anderson, M. Dudìk, S. Ferrier, A. Guisan, R. J.Hijmans, F. Huettmann, J. R. Leathwick, A. Lehmann, J. Li, L. G. Lohmann, B. A. Loiselle, G. Manion, C. Moritz, M. Nakamura, Y. Nakazawa, J. M. Overton, A. T. Peterson, S. J. Phillips, K. Richardson, R. Scachetti-Pereira, R. E. Schapire, J. Soberón, S. Williams, M. S. Wisz, and N. E. Zimmermann. 2006. Novel methods improve prediction of species' distributions from occurrence data. Ecography 29: 129151 .

Foden, W., G. Mace, J. C. Vié, A. Angulo, S. Butchart, L. DeVantier, H. Dublin, A. Gutsche, S. N. Stuart, and E. Turak. 2008. Species susceptibility to climate change impacts. Pp. 1-11 in J. C. Vié, C. Hilton-Taylor and S. N. Stuart (eds.), The 2008 Review of The IUCN Red List of Threatened Species. Gland (Switzerland). IUCN. 14 pp.

Forero-Medina, G., L. Joppa, and S. L. Pimm. 2010. Constraints to species' elevational range shifts as climate changes. Conservation Biology 25: 163-171.

Garrido-Yrigaray, R. R. 1989. Descripción de la larva de Melanophryniscus stelzneri montevidensis (Philippi, 1902) (Anura, Bufonidae). Boletín de la Sociedad Zoológica del Uruguay (2a época) 5: 7-8. 
Gibbs, J. P. and A. R. Breisch. 2001. Climate warming and calling phenology of frogs near Ithaca, New York, 19001999. Conservation Biology 15: 1175-1178.

Gomes-Cortes, L. 2009. Modelagem de distribuição de espécies como ferramenta para a conservação de espécies raras de anfíbios do Cerrado. Unpublished M. Sc. Dissertation. Universidade Federal de Goiás, Brazil.

Hermida, G. N., A. Farías, and L. E. Fiorito de Lopez. 2003. Ultrastructural characteristics of the lung of Melanophryniscus stelzneri stelzneri (Weyenberg, 1875) (Anura, Bufonidae). Biocell 26: 347-355.

Hickling, R., D. B. Roy, J. K. Hill, R. Fox, and C. D. Thomas. 2006. The distributions of a wide range of taxonomic groups are expanding polewards. Global Change Biology 12: 450-455.

IPCC (ed.). 2001. Climate Change 2001: synthesis report. London. IPCC Press. 38 pp.

IUCN. 2013. The IUCN Red List of Threatened Species. Version 2012.2: an Online Reference (1 February 2012). Electronic information accessible at http://www. iucnredlist.org/. International Union for Conservation of Nature and Natural Resources. Captured on 3 June 2012.

Kane, R. P. 2002. Precipitation anomalies in southern America associated with a finer classification of El Niño and La Niña events. International Journal of Climatology 22: $357-373$.

Kottek, M., J. Grieser, C. Beck, B. Rudolf, and F. Rubel. 2006. World map of the Köppen-Geiger climate classification updated. Meteorologische Zeitschrift 15: 259-263.

Langone, J. A. 1994. Ranas y sapos del Uruguay (reconocimiento y aspectos biológicos). Museo Zoológico Municipal Dámaso Antonio Larrañaga, Serie Divulgación 5: 1-123.

Laufer, G. 2012. Lista de especies de anfibios y reptiles de Uruguay vulnerables al cambio climático global. Unpublished report. Instituto de Investigaciones Biológicas Clemente Estable, Ministerio de Educación y Cultura, Uruguay.

Lips, K. R., J. Diffendorfer, J. R III. Mendelson, and M. W. Sears. 2009. Riding the Wave: Reconciling the Roles of Disease and Climate Change in Amphibian Declines. PLoS Biology 6: e72. doi:10.1371/journal. pbio.0060072.

Lobo, J. M., A. Jiménez-Valverde, and J. Hortal. 2010. The uncertain nature of absences and their importance in species distribution modelling. Ecography 33: 103114.
Maneyro R. and S. Carreira. 2012. Guía de Anfibios del Uruguay. Montevideo. Ediciones de la Fuga. 207 pp.

Maneyro, R. and A. Kwet. 2008. Amphibians in the border region between Uruguay and Brazil: updated species list with comments on taxonomy and natural history (Part I: Bufonidae). Stuttgarter Beiträge zur Naturkunde A 1: 95-121.

Maneyro, R. and S. Carreira. 2006. La herpetofauna de la costa uruguaya. Pp. 233-246. in R. Menafra, L. Rodríguez-Gallego, F. Scarabino, and D. Conde (eds.), Bases para la Conservación de la Costa Uruguaya. Montevideo. Editorial Graphis.

Marengo, J. A., M. Rusticucci, O. Penalba, and M. Renom. 2010. An intercomparison of observed and simulated extreme rainfall and temperature events during the last half of the twentieth century. Part 2: historical trends. Climatic Change 98: 509-529

McCallum, M. L. 2007. Amphibian decline or extinction? Current declines dwarf background extinction rate. Journal of Herpetology 41: 483-491.

Navas, C. A. and L. Otani. 2007. Physiology, environmental change, and anuran conservation. Phyllomedusa 6: 83103.

Núñez, D., R. Maneyro, J. A. Langone, and R. O. de Sá. 2004. Distribución geográfica de la fauna de anfibios del Uruguay. Smithsonian Herpetological Information Service 134: 1-34.

Parmesan, C. 2006. Ecological and evolutionary responses to recent climate change. Annual Review of Ecology, Evolution and Systematics 37: 637-669.

Snyder, G. K. and W. W. Weathers. 1975. Temperature adaptations in amphibians. American Naturalist 109: 93-101.

Pearson, R. and T. Dawson. 2003. Predicting the impacts of climate change on the distribution of species: are bioclimate envelope models useful? Global Ecology and Biogeography 12: 361-367.

Phillips, S. A., R. P. Anderson, and R. E. Schapire. 2006. Maximum entropy modeling of species geographic distributions. Ecological Modelling 190: 231-259.

Pounds, J. A., M. P. Fogden, and J. H. Campbell. 1999. Biological response to climate change on a tropical mountain. Nature 398: 611-615.

Pound, J. A., M. R. Bustamante, L. A.Coloma, J. A. Consuegra, M. P. L. Fogden, P. N. Foster, E. La Marca, K. L. Masters, A. Merino-Viteri, R. Puschendorf, S. R. Ron, G. A. Sánchez-Azofeifa, C. J. Still, and B. E. 
Young. 2006. Widespread amphibian extinctions from epidemic disease driven by global warming. Nature 439 : 161-167.

Reading, C. J. 2007. Linking global warming to amphibian declines through its effects on female body condition and survivorship. Oecologia 151: 125-131.

Renom, M. 2009. Temperaturas extremas en Uruguay. Análisis de la variabilidad temporal de baja frecuencia y su relación con la circulación de gran escala. Unpublished Ph.D. Thesis. Universidad de Buenos Aires, Argentina.

Rusticucci, M. and M. Renom. 2008. Variability and trends in indices of quality-controlled daily temperature extremes in Uruguay. International Journal of Climatology 28: 1083-1095.
Rohr, J. R. and T. R. Raffel. 2010. Linking global climate and temperature variability to widespread amphibian declines putatively caused by disease. Proceedings of the National Academy of Sciences USA 107: 8269-8274.

Stuart, S. N., J. S. Chanson, N. A. Cox, B. E. Young, A. S. L. Rodrigues, D. L. Fischman, and R. W. Waller. 2004. Status and trends of amphibian declines and extinctions worldwide. Science 306: 1783-1786.

WorldClim. 2012. WorldClim: global climate data: free climate data for ecological modeling and GIS: an Online Reference (10 April 2012). Electronic Database accessible at http://www.worldclim.org/. Museum of Vertebrate Zoology of the University of California, Berkeley, USA. Captured on 30 May 2012.

Editor: Stephen J. Richards 